\title{
Review of Hawaiian Razorfishes of the Genus Iniistius (Perciformes: Labridae) ${ }^{1}$
}

\author{
Fobn E. Randall and Fohn L. Earle ${ }^{2}$
}

\begin{abstract}
The Indo-Pacific labrid fishes of the genus Xyrichtys Cuvier, popularly referred to as razorfishes, are reclassified in Iniistius Gill. The razorfishes of the Atlantic and eastern Pacific currently placed in Xyrichtys remain in that genus except for the Indo-Pacific Iniistius pavo Valenciennes, which also ranges to the eastern Pacific. The Indo-Pacific Novaculichthys woodi Jenkins, sometimes classified in Novaculops, is shifted to Xyrichtys. Five species of razorfishes of the genus Iniistius are recognized for the Hawaiian Islands: the wide-ranging Indo-Pacific I. aneitensis (Günther), I. baldwini (Jordan \& Evermann), I. pavo, the endemic I. umbrilatus (Jenkins), and I. celebicus (Bleeker), a new record for Hawai'i (otherwise known in the western Pacific from the Mariana Islands, Marshall Islands, and American Samoa). Hemipteronotus evides Jordan \& Richardson is a synonym of I. baldwini. Iniistius niger (Steindachner) is a melanistic color phase of $I$. pavo.
\end{abstract}

The generic classification of the labrid fishes known as razorfishes has a complicated history. Many of the early species were described in the genus Hemipteronotus Lacepède. As explained by Randall and Bauchot (1993), this genus was intended by Lacepède for the Pilotfish (Naucrates ductor), in reference to its short dorsal fin. One razorfish, now Iniistius pentadactylus (Linnaeus), was included in the synonymy of Hemipteronotus, and the genus was later restricted to it. Because both Naucrates and Xyrichtys were threatened by Hemipteronotus, Opinion 1799 of the International Commission on Zoological Nomenclature suppressed Hemipteronotus.

The genus Xyrichtys (from the Greek xyron meaning razor) was described by Cuvier (1814), with the Atlantic Coryphaena novacula Linnaeus as the type species. Randall (1965) reviewed the five species of the genus in the Atlantic (as Hemipteronotus, before the name was suppressed). Victor et al. (2001) wrote that there appear to be six razorfishes of the

\footnotetext{
${ }^{1}$ Manuscript accepted 15 January 2002.

2 Bishop Museum, 1525 Bernice Street, Honolulu, Hawai'i 96817-2704.
}

Pacific Science (2002), vol. 56, no. 4:389-402

(C) 2002 by University of Hawai'i Press

All rights reserved genus Xyrichtys in the eastern Pacific, two of which are undescribed. One of the six, however, is pavo, which we now place in Iniistius.

We noticed the resemblance of some of the eastern Pacific species of Xyrichtys to Novaculops woodi (Jenkins) (sometimes placed in Novaculicbthys), described from the Hawaiian Islands. A comparison of $N$. woodi with Xyrichtys novacula revealed no differences that could be regarded as generic, so we place Novaculops Schultz in the synonymy of Xyrichtys.

Iniistius was proposed by Gill (1862) for the Indo-Pacific and eastern Pacific species Xyrichtys pavo Valenciennes. Jordan (1891:662) wrote, "It is not unlikely that it will be found necessary to unite Iniistius, Hemipteronotus, Xyrichthys, and Xyrula into one genus, as Günther has done." Randall in Smith and Heemstra (1986:705) placed Iniistius in the synonymy of Xyrichtys. However, an unpublished Ph.D. thesis on labrid osteology by Tri-thuc Nguyen (1974) provided the following characters to separate Iniistius and Xyrichtys: the palatine bone overlaps the ectopterygoid in Iniistius, whereas it is separate in Xyrichtys; there are no dorsal pterygiophores between the second and third neural spines of Iniistius but two in Xyrichtys. The skull is notably higher in adult Iniistius than in Xyrichtys. Externally we can separate 
the two genera by the position of the origin of the dorsal fin: it is over or less than half an orbit diameter behind the eyein Iniistius, but more than an eye diameter behind the eye in Xyrichtys. Furthermore, the space between the second and third dorsal spines in Iniistius is much broader than the space between the third and fourth spines, whereas these two spaces are about equal in Xyrichtys. The first two dorsal spines of Iniistius pavo and the related $I$. dea are elongate (especially so in juveniles) and entirely separated from the rest of the fin. Other species of Iniistius have the membrane between the second and third dorsal spines incised, and occasional juveniles of $I$. umbrilatus have the first two dorsal spines and connecting membrane separate (see Plate III $E$ ).

There are four Hawaiian genera of labrid fishes that contain species that are able to exploit food resources over broad open stretches of sand; fishes of these genera avoid approaching predators by diving into the sand. Ammolabrus is represented by a single species, $A$. dicrus Randall \& Carlson, that forms aggregations that feed on zooplankton well above the substratum and only seeks refuge beneath the sand when threatened. Cymolutes consists of three fine-scaled species, only one of which occurs in Hawai'i, the endemic C. lecluse (Quoy \& Gaimard). Xyrichtys (formerly Novaculichthys or Novaculops) contains four Indo-Pacific species, three of which are undescribed; only $X$. woodi (Jenkins) is found in Hawaiian waters. A fourth genus in the same lineage, Novaculichtbys, is represented in Hawai'i by the Rockmover Wrasse, $N$. taeniourus (Lacepède). Although able to bury quickly in sand, it is usually found over coral rubble or rubble-sand areas. A new genus will be described by us for a second species currently classified in the genus Novaculichtbys, the Seagrass Wrasse, N. macrolepidotus (Bloch), not known from the $\mathrm{Ha}$ waiian Islands.

In their comprehensive volume on the shore fishes of the Hawaiian Islands, Jordan and Evermann (1905) included the following razorfishes: Iniistius pavoninus Valenciennes in Cuvier and Valenciennes (in which they placed I. leucozonus Jenkins, 1902, as a syn- onym); Iniistius niger (Steindachner, 1900); Hemipteronotus copei Fowler, 1900; H. umbrilatus Jenkins, 1900; H. jenkinsi Snyder, 1904; H. baldwini Jordan \& Evermann, 1903; and Xyrichtys niveilatus Jordan \& Evermann, 1903.

Fowler (1928) correctly relegated Iniistius pavoninus to the synonymy of $I$. pavo Valenciennes, and Xyrichtys niveilatus to the synonymy of $I$. aneitensis (Günther), but he erred in regarding Hemipteronotus umbrilatus as a synonym of $H$. pentadactylus (Linnaeus), and $H$. baldwini and $H$. jenkinsi as synonyms of $H$. melanopus (Bleeker). He added that his Hemipteronotus copei, with an alleged type locality of O'ahu, "is surely a specimen of Xyrichtbys psittacus (Linné) and likely obtained somewhere in the tropical Atlantic."

In their Handbook of Hawaiian Fishes, Gosline and Brock (1960) correctly placed Hemipteronotus jenkinsi in the synonymy of $H$. baldwini. They listed five species of razorfishes, all with the same generic and species names as Jordan and Evermann.

We also recognize five razorfishes for the Hawaiian Islands, all in the genus Iniistius. We have determined that $I$. niger is a melanistic color phase of $I$. pavo, and we report $I$. celebicus (Bleeker) as a first record for the Islands. Iniistius evides (Jordan \& Richardson, 1909), described from Taiwan, was listed as a synonym of $I$. baldwini by Randall (1996:142) without documentation; confirmation is provided here.

All five of the Hawaiian species of Iniistius inhabit the extensive sand area off Kahe Point on the Wai'anae coast of O'ahu. For over a decade J.L.E. has made periodic surveys for razorfishes, including transects, near the Kahe Power Plant warm-water outflow. This study is ongoing, but some ecological and life history notes have been included in the Remarks section for each species.

Specimens were examined at the National Museum of Natural History, Washington, D.C. (usnm), and Bernice P. Bishop Museum, Honolulu (врвм). Lengths of specimens are given as standard length (SL), measured from the front of the upper lip to the base of the caudal fin. Gill-raker counts include all rudiments. 
Genus Iniistius Gill

Iniistius Gill, 1862:143 (type species, Xyrichtys pavo Valenciennes, by original designation).

Duobemipteronotus Fowler, 1956:281 (type species, Hemipteronotus evides Jordan \& Richardson, by original designation; proposed as a subgenus).

DIAGNosis: Dorsal-fin rays IX,12; analfin rays III,12; pectoral-fin rays 12 ; pelvic-fin rays I,5; principal caudal rays 12 ; lateral line interrupted, 19-22+4-6 (usually $20+5$ ); gill rakers short, 15-25; branchiostegal rays 5; vertebrae 25; body depth $2.3-3.3$ in SL, the depth increasing with growth; body very compressed, especially in adults, the width about one-third body depth; snout long (as result of deep suborbital region), its dorsal profile steep in adults, nearly vertical in some large adults; remainder of head profile strongly convex; fleshy anterior edge of head of adults a sharp ridge; a fleshy flange at edge of posterior half of orbit, narrowest posteriorly; mouth small to moderate, horizontal to slightly oblique, with a pair of long curved canines anteriorly in each jaw that extend above and below lips when mouth closed, the lowers fitting inside the uppers; no canine tooth at corner of mouth; side of jaws with a row of stout conical teeth and an inner band of small nodular teeth; scales cycloid, thin, but adherent; scales on chest about half size of those on side of body; head naked except for scales on side of nape posterior to eye, 14 scales dorsoanteriorly on opercle, and small scales on suborbital region (none to a few in $I$. pavo); no scales basally on dorsal and anal fins; origin of dorsal fin anterior to upper end of gill opening; first 2 spines of dorsal fin flexible and separated by a broad gap from rest of fin,
TABLE 1

Gill-Raker Counts of Hawaiian Species of Iniistius

\begin{tabular}{lrrrrrrrr}
\hline \hline Species & 16 & 17 & 18 & 19 & 20 & 21 & 22 & 23 \\
\hline anietensis & & & & 5 & 8 & 8 & 6 & 2 \\
baldwini & & & 4 & 6 & 3 & 1 & & \\
celebicus & & & 2 & 2 & 5 & 6 & 1 & \\
pavo & & 2 & 1 & 15 & 16 & 2 & & \\
umbrilatus & 4 & 11 & 9 & 3 & & & & \\
\hline
\end{tabular}

with or without a low membranous connection; caudal fin short, slightly emarginate to rounded (usually slightly rounded).

REMARKs: The species of Iniistius have the same fin-ray and lateral-line scale counts. The only meristic character of value is the number of gill rakers. However, as can be seen from Table 1, there is broad overlap in these counts for most Hawaiian species. The pattern of scales on the suborbital region is helpful in classification. Some species have only a single oblique series of small scales from below the middle of the eye to behind the lower part of the eye, whereas others have a broad band of small scales in several vertical rows extending to behind the corner of the mouth or slightly below. Still others have a triangular band of scales that extends ventrally to various degrees but not to the level of the corner of the mouth. Fortunately, most of the species have distinctive color patterns as adults that allow identification. The dark-barred juveniles of some related species, however, may be difficult to distinguish by color pattern. Juveniles undergo dramatic change in morphology with growth. The body depth increases proportionately, the suborbital depth increases greatly, and the dorsal profile of the snout becomes much steeper.

\section{KEY TO THE HAWAIIAN SPECIES OF Iniistius}

1a. Origin of dorsal fin over posterior half of eye; first two dorsal-fin spines and connecting membrane completely separate from remainder of fin, the first spine nearly twice as long as longest soft ray of fin in adults (to nearly three times longer in juveniles); adults with a small black spot, broadly edged anteriorly with bluish white, below base of sixth dorsal spine, partly on eighth lateral-line scale; occasional individuals (mainly juveniles, rarely adults) entirely dark brown to black except for translucent white outer part of caudal fin.............................................. pavo 
1b. Origin of dorsal fin posterior to a vertical at hind edge of eye; first two dorsal-fin spines joined by membrane (although deeply incised, and rarely without membrane in juvenile umbrilatus) to rest of fin, the first spine of adults at most slightly longer than longest dorsal soft ray (first spine of juvenile I. baldwini and I. umbrilatus may be 1.52 times longer than longest dorsal soft ray); color not as in $1 \mathrm{a} \ldots \ldots \ldots \ldots \ldots \ldots .2$

2a. Suborbital region with a broad band of small scales beginning with 6-7 vertical rows just below eye and extending to or below level of corner of mouth, with 2-4 rows

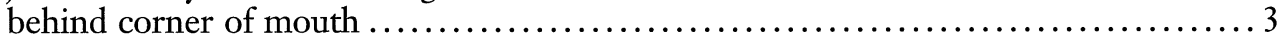

2b. Suborbital region with either a single oblique row of small scales from below middle of eye to behind lower part of eye, or a triangular patch of small scales that does not extend to behind corner of mouth...................................... 4

3a. Adults with a broad, dark brown to black bar on side of body extending from about lateral-line scales 7 to 12 to level of lower edge of pectoral fin; juveniles with a narrow dark bar from nape across opercle, three across body (two of which end in an ocellated black spot in dorsal fin), and a chevron-shaped one on caudal-fin base; smaller juveniles with first two and third and fourth bars nearly fully joined as two very broad dark bars; gill rakers $16-19$ (modally 17 ).................. I. umbrilatus

3b. Adults without dark bars on body; an oval to subtriangular reddish black spot below seventh to ninth dorsal spines, bisected by lateral line; a large oval white blotch below black spot, broadly bordered above and anteriorly by yellow; edge of membrane just behind second dorsal spine narrowly black; a small blackish spot distally on third and fourth dorsal-fin membranes; a large black spot submarginally on last one to four membranes of anal fin; juveniles with a smaller black spot on lateral line, not reaching base of dorsal fin, and with small blackish spots along lateral line; gill rakers

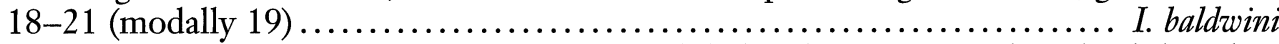

4a. Adults with a black spot smaller than eye on back below base of second to third dorsal soft rays, and three less distinct spots, one below first and second dorsal spines, one below sixth spine, and one below eighth to ninth soft rays, all four spots often with a blackish bar extending below; a large, round, bluish white spot on upper abdomen centered below outer part of pectoral fin, with a large adjacent yellow area in front; juveniles with broader and darker blackish bars (some juveniles entirely dark brown except for whitish front of head and outer half of caudal fin) ............. aneitensis

4b. A large red to dark reddish brown, oval blotch anteriorly on side of body, covered in its lower part by pectoral fin; a horizontally elongate blackish blotch midlaterally on posterior caudal peduncle and extending onto caudal-fin base (blotch sometimes preceded by an irregular blackish stripe or, on juveniles, by two separate midlateral

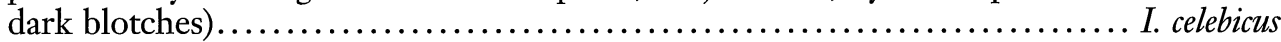

\section{Iniistius aneitensis (Günther)} Plate I $A-D$

Novacula aneitensis Günther, 1862:176 (type locality, Aneiteum = Anatom, Vanuatu).

Xyrichthys niveilatus Jordan \& Evermann, 1903:194 (type locality, Honolulu); Jordan \& Evermann, 1905:337, fig. 142.

Hemipteronotus liogenys Fowler, 1904:539, pl. 20, lower fig. (type locality, Padang, Sumatra).
DiAgNosis: An oblique row of small scales from below middle of eye to behind lower part of eye, some specimens with one to four short rows of small scales (or single scales) below first row; gill rakers 19-23 (modally 20-21); body depth 2.4-3.1 in SL; origin of dorsal fin slightly anterior to a vertical at upper end of preopercular margin; first two dorsal spines flexible, the first curved, and not longer than longest dorsal soft ray; membrane between second and third 
dorsal spines incised more than half length of third spine. Color of adults light gray with a black spot, usually the size of eye or smaller, on back below base of second to third dorsal soft rays; a very large, round, white to bluish white spot on upper abdomen centered below tip of pectoral fin, this spot usually preceded by a yellow to yellowish brown or blackish blotch; less distinct blackish spots may be present on back below first and second dorsal spine, sixth spine, and eighth to ninth dorsal soft rays (each spot may have a dusky to blackish bar descending from it across body); a blue line (often faint) extending ventrally from front edge of orbit; dorsal and anal fins irregularly marked with pale yellow and pale blue; males with a narrow vertical pale blue bar, edged in darker blue, on each scale, these bars broader posteriorly on body. Juveniles with a narrow, dark brown bar from below front of eye, a dark bar from nape across opercle, three dark bars on body (may be very broad, especially ventrally); and a diffuse short dark bar or blotch at base of caudal fin; third and fourth bars often ending in an ocellated, oval black spot in soft portion of dorsal fin (vestiges of these spots may be present in specimens as large as $80 \mathrm{~mm}$, but specimens as small as $50 \mathrm{~mm}$ may lack spots); some juveniles dark brown, almost masking darker brown bars; rarely a very dark brown to black juvenile (Plate I $B$ ) except for most of unscaled part of caudal fin, a small posterior part of dorsal fin, and anterior edge of head, including front of lips, which are white. Largest specimen examined, the holotype, USNM 50646, $196 \mathrm{~mm}$.

REMARKs: Iniistius aneitensis is known from the Hawaiian Islands and American Samoa (Wass 1984) to the western Pacific, where it ranges from the Ryukyu Islands (Masuda et al. 1975:305, pl. $111 D$ ) and Taiwan (Shao 1986:185, figs. 10, 11; Shen and Yeh 1987:64, fig. 11) to the Great Barrier Reef (Randall et al. 1990:340, lower fig.) and Lord Howe Island (Francis 1993). There are Indian Ocean records from Zanzibar (Playfair and Günther 1867:97), Maldive Islands (Randall and Anderson 1993:35) and the Chagos Archipelago (Winterbottom and Anderson 1997:16).
Specimens in the Bishop Museum have been collected from depths of 4 to $35 \mathrm{~m}$. Randall et al. (1985:62) reported the species at a depth of $92 \mathrm{~m}$ at Johnston Island by observation from a submersible.

Iniisitius aneitensis is widely distributed in suitable sandy habitat in the Hawaiian Islands, though the population off Kahe Point and other locations on $\mathrm{O}^{\prime} \mathrm{ahu}$ is smaller than that of I. umbrilatus. In J.L.E.'s shallow transect area at 5-10 m depth at Kahe Point, the ratio of the two species is $13: 1$. A higher percentage of $I$. aneitensis has been observed on sandy areas off reefs at about $15 \mathrm{~m}$ depth. These occur in aggregations of from 3 to 11 adults, with a population structure of individual female territories within the territory of a dominant male similar to that of I. umbrilatus and other Hawaiian species of Iniistius except I. celebicus.

MATERIAL EXAMINED: Hawaiian Islands, O'ahu, Honolulu, usNM 50646, $196 \mathrm{~mm}$ (holotype of Xyrichthys niveilatus Jordan \& Evermann). O'ahu, врвм 23530, $168 \mathrm{~mm}$; врвм 31329, $58 \mathrm{~mm}$; вРвм 32860, $45 \mathrm{~mm}$; вРвм $37126,54 \mathrm{~mm}$; вРвм 37187,134 mm; врвм 37293, 46 mm; врвм 37294, 49 $\mathrm{mm}$; врвм 37298, $49 \mathrm{~mm}$. Kaho'olawe, врвм 12719, $181 \mathrm{~mm}$. Hawai'i, врвм 8167, 137 mm; врвм 29289, $105 \mathrm{~mm}$. American Samoa, Tutuila, врвм 22727, 5: 63-132 mm. Marshall Islands, Kwajalein Atoll, врвм 37275, 2: 127-158 mm. Enewetak Atoll, вРвм 18392, 34: 47-103 mm; вРвм 27809, 2: 75-75.5 mm; врвм 29172, 2: 20-63 mm. Mariana Islands, Guam, врвм 37055, $155 \mathrm{~mm}$. Vanuatu, Aubrym Island, USNM 350123, 4: 77-81 mm. Lord Howe Island, врвм 35032, $80 \mathrm{~mm}$. Indonesia, Watubela Islands, вРвм 36602, $104 \mathrm{~mm}$.

\section{Iniistius baldwini (Jordan \& Evermann)} Plate I $E-H$; Plate II $A, B$

Hemipteronotus baldwini Jordan \& Evermann, 1903:192 (type locality, Honolulu); Jordan \& Evermann, 1905:334, pl. 39.

Hemipteronotus jenkinsi Snyder, 1904:530, pl. 10, fig. 19 (type locality, Puakō Bay, Hawai'i). 
Hemipteronotus evides Jordan \& Richardson, 1909:196, pl. 72 (type locality, Takao = Kaoshiung, Taiwan).

DIAGNosis: Suborbital with a broad band of small scales beginning with 6-7 rows just below eye and ending below corner of mouth (with 2-4 rows behind corner of mouth); gill rakers 18-21 (modally 19); body depth 2.53.4 in SL; origin of dorsal fin in adults slightly posterior to a vertical at rear edge of orbit; first two dorsal spines flexible, the first curved and not longer than longest dorsal soft ray; first dorsal spine of juveniles may be 1.5 times longer than longest dorsal soft ray; membrane between second and third dorsal spines incised three-fourths or more length of third spine. Color of adult males light gray, the scales posteriorly on body yellowish with a large bluish gray center; a large, oval to subtriangular, reddish black spot on back extending from beneath seventh to ninth dorsal spines to below lateral for a distance about equal to its length above lateral line; a large, oval, white spot below black spot, centered beneath tip of pectoral fin and broadly bordered by dusky yellow dorsally and anteriorly; dorsal fin pale yellow with pale blue oblique bands and circles basally on membranes; one specimen with a black spot on last ray; anterior half of incised second dorsal-fin membrane with a conspicuous black edge; a small blackish spot distally on third, fourth, and sometimes fifth membranes of dorsal fin; anal fin pale translucent yellow with oblique pale blue bars, the last one to four membranes with a broad submarginal black band; membranes of caudal fin pale yellow with small blue spots on each that form irregular vertical rows; females lack the black band posteriorly in anal fin. Juveniles light gray with a smaller black spot on lateral line (still its length about twice orbit diameter), usually not reaching base of dorsal spines; a few scattered small blackish spots along lateral line just above tubule of pored scales; oval white spot present on body below black spot; fins translucent without black markings. Largest specimen examined, ВРвм 15023, $210 \mathrm{~mm}$, from off O'ahu.

REMARKS: Randall (1996:142) wrote that
Xyrichtys evides (Jordan \& Richardson) is a synonym of baldwini, but without documentation. $\mathrm{He}$ was followed by Eschmeyer (1998:552) and Parenti and Randall (2000: 48). Juveniles of the two nominal species look the same except for the larger black spot on the lateral line of baldwini. A comparison is provided here from an underwater photograph of an adult male of the "evides" form taken in $30 \mathrm{~m}$ at Normanby Island, D'Entrecasteaux Islands, Papua New Guinea, and a male from O'ahu photographed after removal from the sea (hence with the life color a little faded). Both fish have the elongate black spot suffused with red in the same position on the lateral line, the oval white blotch of the same size below the black spot, edged above and in front by yellow, the very characteristic black marking posteriorly in the anal fin, and the same pale yellow median fins with pale blue markings. The only differences seem to be the broader black spot of baldwini and the small black markings distally on the anterior part of the dorsal fin of baldwini. Dor and Fraser-Brunner (1977:135, fig. 1) recorded Xyrichtys melanopus from a single specimen $174 \mathrm{~mm}$ SL collected in the Red Sea off Eritrea, but their fish appears to be Iniistius baldwini. The black spot below the eighth and ninth dorsal spines of the Red Sea specimen is slightly broader than the spot of adult $\mathrm{Ha}$ waiian specimens of baldwini.

The razorfish identified as Xyrichtys evides and illustrated in color from Japan by Masuda et al. (1984: pl. 207 I) and from Taiwan by Shen and Yeh (1987: figs. 8-20) is not this species. It may prove to be Iniistius spilonotus (Bleeker) or an undescribed species.

Bishop Museum specimens of Iniistius baldwini from the Hawaiian Islands have been collected over sand from depths of 15-32 m.

At Kahe Point on O'ahu, all life stages of Iniistius baldwini favor deeper water than the other species of the genus. Juveniles form small groups of widely spaced individuals off reef promontories at depths of about $15 \mathrm{~m}$. Colonies of adults are found offshore beyond the habitat of adult I. umbrilatus, far from the nearest reef, at $18-20 \mathrm{~m}$. Female territories are large and widely spaced. The extent of a male's territory can best be determined by 


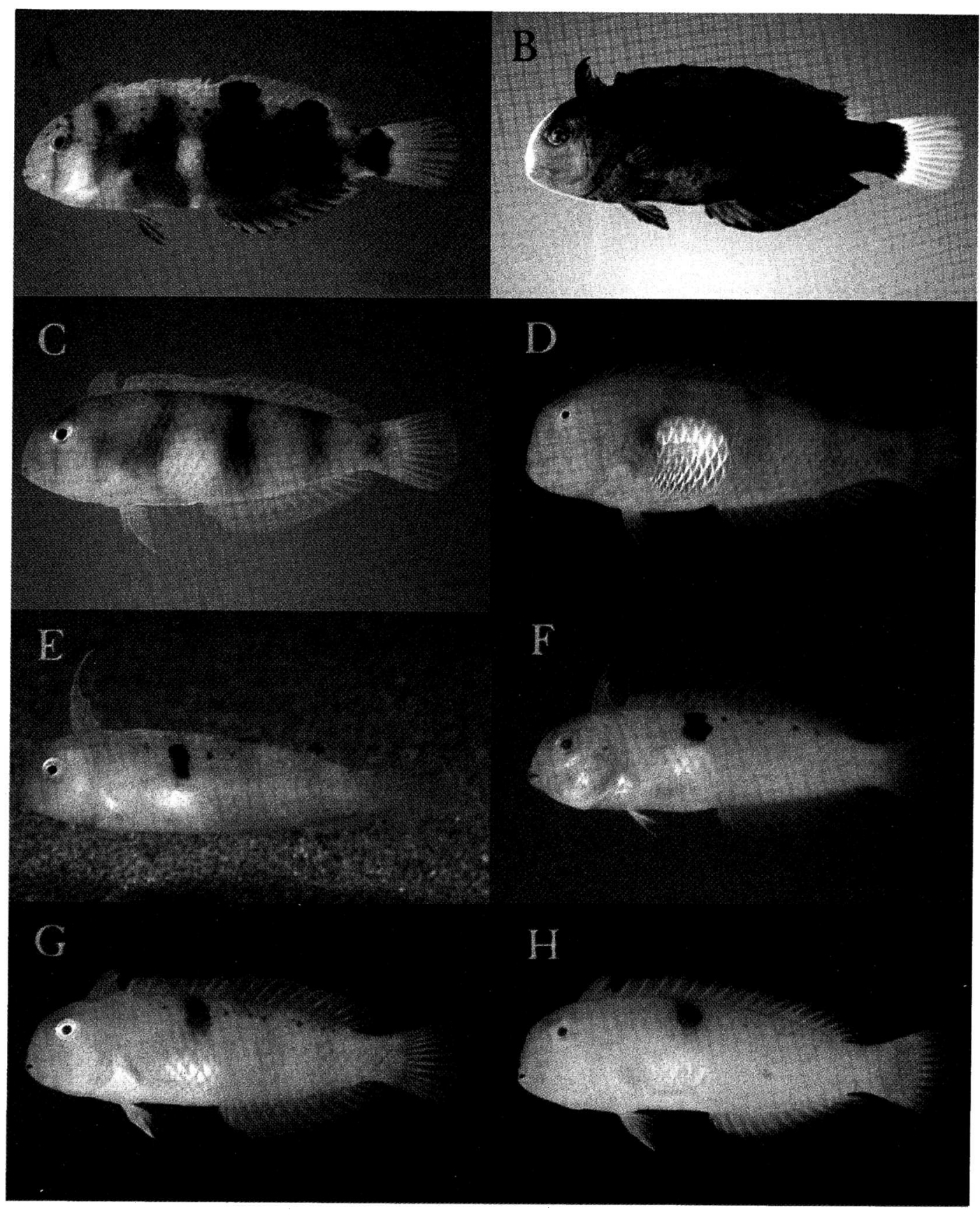

Plate I. A. Iniistius aneitensis, врвм 37293, $46 \mathrm{~mm}$ SL, Makua, O'ahu. B. Iniistius aneitensis, врвм 37294, $49 \mathrm{~mm}$ SL, Kahe Point, O'ahu. C. Iniistius aneitensis, врвм 37126, 54 mm SL, Kahe Point, O’ahu. D. Iniistius aneitensis, вPвм 8167, 137 mm SL, Kona, Hawai'i. E. Iniistius baldwini, juvenile, underwater photo, Kahe Point, O'ahu. F. Iniistius baldwini, врвм 37301, $49 \mathrm{~mm}$ SL, Kahe Point, O'ahu. G. Iniistius baldwini, specimen lost, $72 \mathrm{~mm}$ SL, Kahe Point, O'ahu. H. Iniistius baldwini, врвм 37244, 103 mm SL, Kahe Point, O'ahu. 


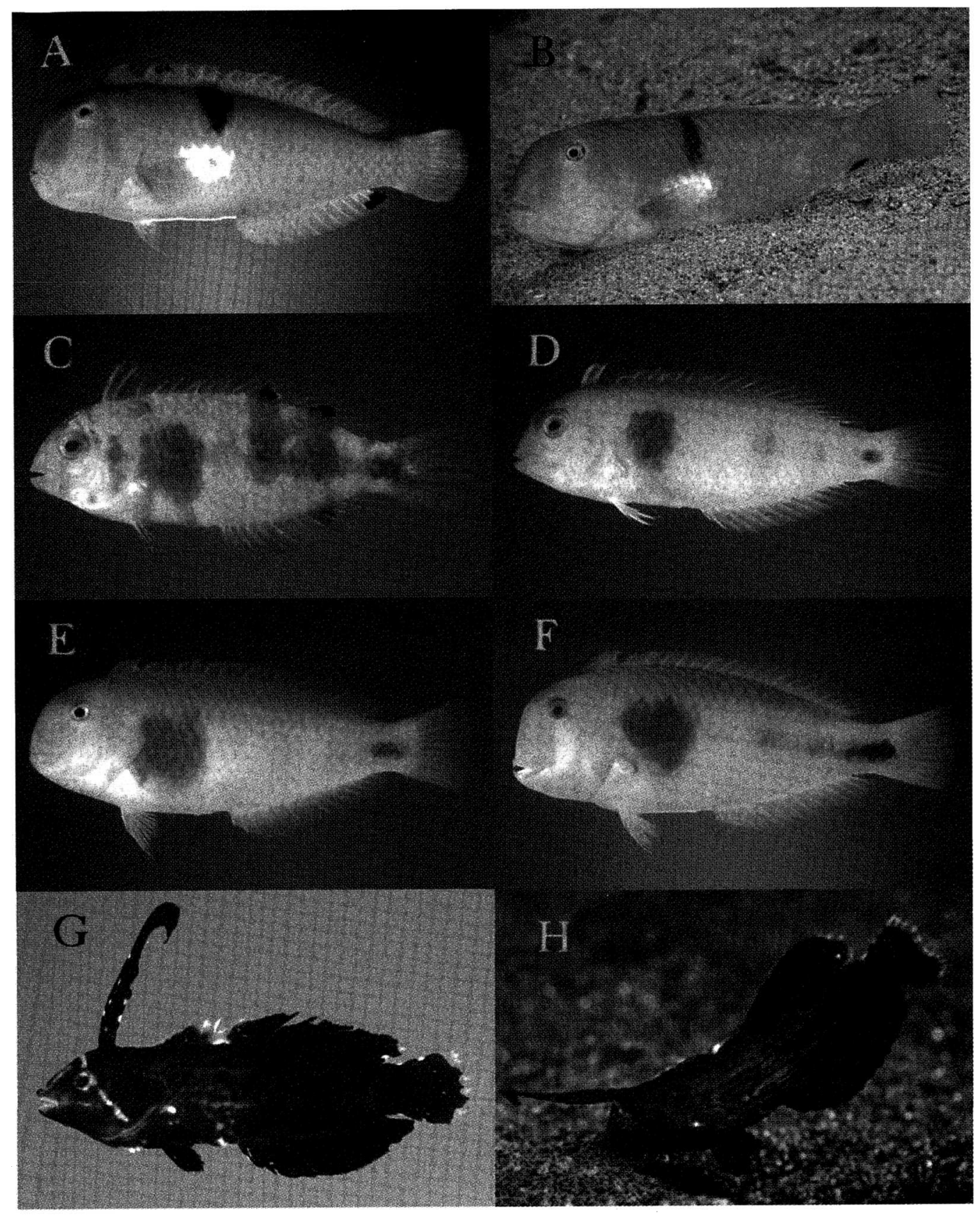

Plate II. A. Iniistius baldwini, врвм 27068, $204 \mathrm{~mm} \mathrm{SL}$, off Honolulu Airport, O'ahu. B. Iniistius baldwini, underwater photo, врвм 36222, $172 \mathrm{~mm}$ SL, D'Entrecasteaux Islands. C. Iniistius celebicus, врвм 37288, $34 \mathrm{~mm}$ SL, Kahe Point, O'ahu. D. Iniistius celebicus, врвм 37289, $48 \mathrm{~mm}$ SL, Kahe Point, O'ahu. E. Iniistius celebicus, врвм 36829 , $99 \mathrm{~mm}$ SL, Bolinao, Luzon, Philippines. F. Iniistius celebicus, врвм 37292, $140 \mathrm{~mm}$ SL, Kahe Point, O'ahu. G. Iniistius pavo, в ввм 31018, $22 \mathrm{~mm}$ SL, Kahe Point, O'ahu. H. Iniistius pavo, underwater photo, juvenile, about $60 \mathrm{~mm}$ TL, Bali, Indonesia. 




Plate III. A. Iniistius pavo, врвм 7921, $90 \mathrm{~mm}$ SL, Pūpükea, O‘ahu. B. Iniistius pavo, female, в.Pвм 11647, $179 \mathrm{~mm}$ SL, Honolulu fish market. C. Iniistius pavo, male, врвм 11647, $259 \mathrm{~mm}$ SL, Honolulu fish market. D. Iniistius umbrilatus, врвм 37205, $21 \mathrm{~mm}$ SL, Makua, O'ahu. E. Iniistius umbrilatus, underwater photo, врвм 36785, $32 \mathrm{~mm}$ SL, West Maui. F. Iniistius umbrilatus, врвм 37190, $47 \mathrm{~mm} \mathrm{SL,} \mathrm{Makua,} \mathrm{O‘ahu.} \mathrm{G.} \mathrm{Iniistius} \mathrm{umbrilatus,} \mathrm{врвм} \mathrm{37127,} 57 \mathrm{~mm} \mathrm{SL}$, Kahe Point, $O^{`}$ ahu. H. Iniistius umbrilatus, underwater photo, about $200 \mathrm{~mm}$ TL, Kahe Point, O`ahu. 

following an individual male as females of his harem are sequentially visited. Each individual, whether male or female, has several preferred spots for diving into the sand throughout its territory, generally visible as a slight dimple or depression in the sand. When threatened, the fish will swim to the nearest such spot and hover above it. If the intruder is perceived as inadequately threatening, the fish can flee to another of its dive sites rather than dive into the sand.

MATERIAL EXAMINED: Hawaiian Islands, O'ahu, Honolulu, UsNm 50644, $179 \mathrm{~mm}$ (holotype of Hemipteronotus baldwini Jordan \& Evermann); USNM 55359, 4: 124-147 mm (paratypes of $H$. baldwini); USNM 50879, $209 \mathrm{~mm}$ (holotype of Hemipteronotus jenkinsi Snyder). O'ahu, врвм 4708-10, 3: 160-170 $\mathrm{mm}$; вРвм 10523, $210 \mathrm{~mm}$; вРВм 15410, 148 $\mathrm{mm}$; вРвм 27068, $204 \mathrm{~mm}$; вРвм 37088, $197 \mathrm{~mm}$; вРвм 37237, $175 \mathrm{~mm}$; вРвм 37244, $103 \mathrm{~mm}$; врвм 37301, $49 \mathrm{~mm}$. Papua New Guinea, D'Entrecasteaux Islands, Normanby Island, врвм 36222, 2: 157-172 mm.

\section{Iniistius celebicus (Bleeker)} Plate II $C-F$

Novacula celebica Bleeker, 1856:61 (type locality, Makassar, Sulawesi, Indonesia).

Hemipteronotus celebicus Bleeker, 1862:153, pl. 30, fig. 5 (Sulawesi and Ambon).

Xyrichtys sp. 2 Shen \& Yeh, 1987:65, figs. 1314 (Taiwan).

Xyrichtys pavo (non Valenciennes) Hoover, 1993:160, lower fig. (Hawaiian Islands).

Xyrichtys sp. Randall, Ida, Kato, Pyle, \& Earle, 1997:49, pl. $14 A$ (Ogasawara Islands).

DIAGNosis: A single oblique row of small scales from below middle of eye to behind lower part of eye or a narrow triangular band of small scales that may extend nearly to level of corner of mouth (as shown in Bleeker 1862: pl. 30, fig. 5), or a scale pattern intermediate to these two patterns; gill rakers 18-22 (modally 20 and 21); depth of body 2.3-2.9 in SL; origin of dorsal fin slightly posterior to a vertical at posterior edge of orbit; first two dorsal spines flexible, the first curved, neither longer than longest dorsal soft ray; membrane between second and third dorsal spines incised more than three-fourths length of third dorsal spine. Color of adults pale gray brown, shading to white ventrally, the edges of the scales dorsally on body narrowly darker gray brown; a large, vertically oval to heart-shaped, dark yellowish brown to reddish black spot on side of body just behind gill opening, overlaid in its ventral part by pectoral fin; a horizontally oval, dark yellowish brown to dark brown spot midlaterally across caudal-fin base, often preceded by a blackish streak or by two blackish blotches; fins translucent white to pale yellow. Juveniles with the same large dark spot anteriorly on side of body but with two bars projecting below, one to base of pelvic fins and one ending midventrally on abdomen; two broad dark bars extending from slightly below midlateral line into soft portion of the dorsal fin where they end in an ocellated black spot; a horizontally oval dark blotch midlaterally on posterior caudal peduncle and caudal-fin base; a short dark bar on opercle and a narrow orange bar extending ventrally from anterior part of eye.

REMARKs: Bleeker (1862: pls. 29 and 30) illustrated five species of razorfishes (all in Hemipteronotus) with a large red spot anteriorly on side of body. From our observation, only Iniistius twistii has the spot entirely red. In I. melanopus and I. spilonotus (if distinct from melanopus), the spot is bluish white and yellow. The male of $I$. pentadactylus has no red spot on the abdomen. We have seen no individuals of $I$. celebicus with an entirely red spot, but ones we collected from Middleton Reef off Queensland had spots with a large amount of red mixed with black.

Iniistius celebicus is reported here as a first record for the Hawaiian Islands. We could find no differences in Hawaiian specimens of this species from specimens of other Pacific localities. All of our Hawaiian specimens were collected or photographed off $\mathrm{O}^{\prime} \mathrm{ahu}$, but the species has been observed underwater by J.L.E. in large colonies off Kāanapali, Maui. In addition to Indonesia, it has been reported from the Philippines (Herre 1953:676); Bikini Atoll, Marshall Islands (Schultz in 
Schultz and Collaborators 1960:152); American Samoa (Wass 1984:23); Taiwan (Shen and Yeh 1987:65, as Xyrichtys sp. 2); Guam, Mariana Islands (Myers and Donaldson 1996:244, fig. 6 f; Myers 1999:195, pl. 118 C); and the Ogasawara Islands (Randall et al. 1997:49, pl. $14 A$, as Xyrichtys sp.).

The two areas where Iniistius celebicus has been found ( $\mathrm{O}^{\prime} \mathrm{ahu}$ and Maui) are protected from seasonal extemes of big surf but with good current flow; we have observed the species from depths of 7.5-15 m. The young settle out, mainly in spring, close to a reef among similar-sized and initially similarlooking juveniles of $I$. umbrilatus. We have collected what we believe to be newly settled umbrilatus at about $12 \mathrm{~mm}$ SL and presume that celebicus may be about the same size when recruiting. The two species form small, samespecies groups at about $55 \mathrm{~mm}$ SL.

Mature females of Iniistius celebicus do not appear to have individual territories, but rather forage together in a loose, moving aggregation, generally remaining close to the reef where they first settled out.

When courting, the larger male periodically joins and swims rapidly among a group of females, assuming a bluish color with two broad, light-colored stripes, one above and one below the dark midlateral zone on the posterior half of the body. One spawning event was observed similar to that described below for I. umbrilatus except that the male had a rapid rolling motion around the female during the release of gametes.

At all sizes, Iniistius celebicus is more wary than I. umbrilatus and the other Hawaiian species and more inclined to move away or dive into the sand at a diver's approach. It has been overlooked previously in Hawai' $i$, possibly because of its wariness, its patchy distribution, and its similar appearance to $I$. umbrilatus (both have a dark side blotch when seen underwater).

MATERIAL EXAmined: Coral Sea, Middleton Reef, врвм 35028, 4: 125-146 mm. Philippines, Luzon, Bolinao, врвм 36829, 99 mm. Japan, Ogasawara Islands, Chichi-jima, врвм 35174, $99 \mathrm{~mm}$; Ani-jima, врвм 35068, $56 \mathrm{~mm}$; вРвм $35162,115 \mathrm{~mm}$. Mariana Islands, Guam, врвм 36534, 2: 68-85 mm.
Marshall Islands, Kwajalein Atoll, врвм 37277, 2: 61-68 mm. Enewetak Atoll, врвм 7274, $39 \mathrm{~mm}$. Hawaiian Islands, O'ahu, вРвм 37082, $102 \mathrm{~mm}$; вРвм 37289, $48 \mathrm{~mm}$; врвм $37292,140 \mathrm{~mm}$; вРвм $37288,2: 34-48$ $\mathrm{mm}$.

\section{Iniistius pavo (Valenciennes)}

Figure 1; Plate II $G-H$; Plate III $A-C$

Xyrichtbys pavo Valenciennes in Cuvier \& Valenciennes, 1840:61, pl. 394 (type locality, Mauritius).

Xyrichtbys pavoninus Valenciennes in Cuvier \& Valenciennes, 1840:63 (type locality, Hawaiian Islands).

Novacula tessellata Valenciennes in Cuvier \& Valenciennes, 1840:74 (type locality, Mauritius).

Novacula immaculata Valenciennes in Cuvier \& Valenciennes, 1840:75 (type locality, Mauritius).

Xyrichtbys puniceus Richardson, 1846:261 (type locality, Canton = Guangzhou, China).

Novacula tetrazona Bleeker, 1859:169 (type locality, Bali, Indonesia).

Iniistius mundicorpus Gill, 1862:145 (type locality, Cabo San Lucas, Baja California).

Novacula (Xirichtbys) carneoflava Peters, 1877:843 (type locality, Dana Island).

Novacula (Iniistius) nigra Steindachner, 1900:176 (type locality, Honolulu).

Iniistius leucozonus Jenkins, 1901:54, fig. 11 (type locality, Hawaiian Islands).

Iniistius verator Jenkins, 1901:55, fig. 12 (type locality, Honolulu).

Iniistius cacatua Waite, 1901:41, pl. 7 (type locality, Lord Howe Island).

Iniistius niger Jenkins, 1903:465 (Hawaiian Islands).

Novacula temporalis Regan, 1905:392, pl. 6, fig. 3 (type locality, Réunion).

Xyricbthys panamensis Fowler, 1944:267, fig. 234 (type locality, Perlas Islands, Panama, eastern Pacific).

DIAGNosis: Suborbital region usually with 1-6 small scales (often embedded, sometimes absent) in an oblique row from behind lower part of orbit to below posterior edge of 


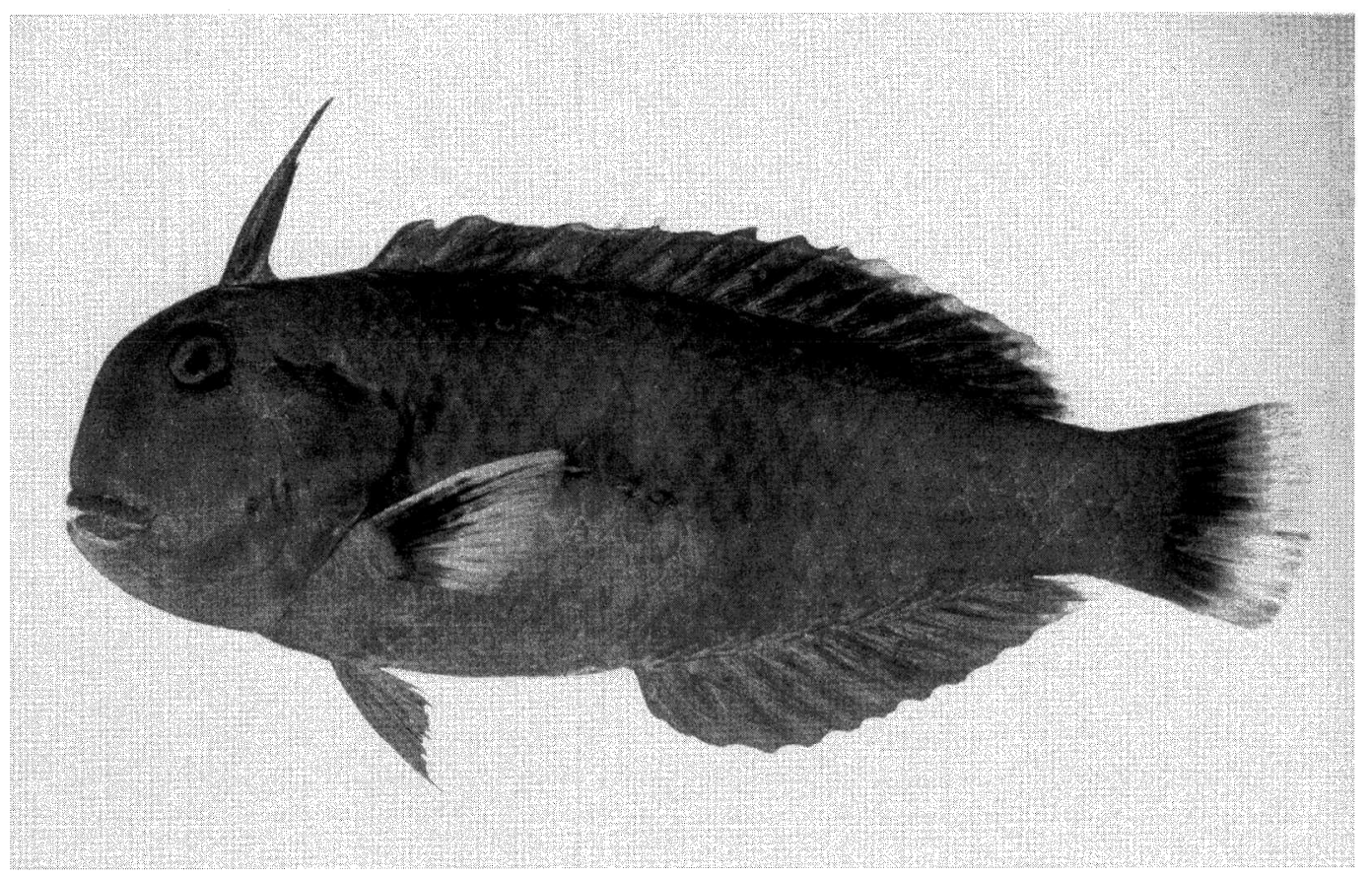

FIgURE 1. Black phase of Iniistius pavo, вРвм 17647, $159 \mathrm{~mm}$ SL, Maui.

orbit; 1 or 2 scales dorsoposteriorly on opercle; gill rakers 17-21 (modally 19 and 20); body depth $2.3-3.3$ in SL (increasing with growth); origin of dorsal fin over posterior half of orbit, the first two spines flexible (all spines may be flexible in adults), separated from third spine by a gap as great as three times that of other adjacent spines; first dorsal spine (and to a lesser extent the second spine) nearly twice as long as longest dorsal soft ray in adults (may be three times length of longest dorsal soft ray in juveniles and with a broad posterior membrane that is expanded as a flap distally); pelvic fins of variable length, 1.3-2.2 in head length, often reaching anus and sometimes extending beyond origin of anal fin (pelvic fins of other Hawaiian species not approaching anus). Color of adults gray to brownish gray, the scale edges darker than centers, shading to white ventrally, with three indistinct broad, darker gray bars on body and one across caudal-fin base; a large, roundish, pale yellowish area on lower side centered beneath tip of pectoral fin; a vertically elongate (often hemielliptical) black spot slightly smaller than a scale on eighth lateral-line scale and the scale dorsoanterior to it, this spot usually edged anteriorly with bluish white; one to a few scales ventrally in middle dark bar of body often with a black edge preceded by pale blue; front of head gray with a median orange-edged blue line extending onto chin; operculum dark except for a pale edge just behind posterior margin of preopercle; males with a vertical darkedged blue line on each scale on about ventral half of body, the blue brighter on scales within dark bars; median fins with a pale blue submarginal line, the dorsal and anal with irregular oblique blue lines. Juveniles with dark bars on body more distinct, two of which extend into base of soft portion of dorsal fin where they contain an ocellated black spot (variously lost with growth); some juveniles with longitudinal dotted dark brown lines following scale rows and an oblique, dark-edged pale band across head through eye; still other juveniles entirely black except for outer trans- 
parent part of caudal fin and posterior tip of dorsal fin. Occasional individuals retain the black coloration to adult size, but the black spot on the lateral line can usually be detected on close inspection. Largest specimen examined, врвм 4712, $305 \mathrm{~mm}$ SL.

REMARKS: Iniistius pavo is the most widespread of the Indo-Pacific species, occurring from the Red Sea south on the coast of East Africa to Natal (Randall in Smith and Heemstra 1986:706), east to the Hawaiian Islands, islands of French Polynesia, and the Pitcairn Islands (Randall 1999:23). In the western $\mathrm{Pa}-$ cific it ranges from Tanabe Bay, Japan (Masuda et al. 1975:305, pl. $111 E, G, H$ [the latter two as juveniles misidentified as Hemipteronotus dea]), south to the Great Barrier Reef (Randall et al. 1990:341, upper 2 figs.), New South Wales (see Other Material Examined), Lord Howe Island (Allen et al. 1976:420), and New Caledonia (Laboute and Grandperrin 2000:371). It also occurs in the eastern Pacific from the Gulf of California to Panama and the Galápagos Islands (Allen and Robertson 1994:208, upper 2 figs.; Grove and Lavenberg 1997:498, fig. 279). It is the best represented Indo-Pacific species of the genus in museum collections. As can be seen from the synonymy, it has the most junior synonyms.

Iniistius niger has long been regarded as a valid species. That it is only a melanistic color form of $I$. pavo was suspected when individuals of intermediate color were noted. Final confirmation came from the staff of the oceanarium of the Maui Ocean Center, where they observed the full change of a black individual into the typical pale color pattern. We also determined that the range in gill-raker counts is exactly the same for both color forms.

A syntype of Xyrichtys pavo (MNHN A.9088, $295 \mathrm{~mm} \mathrm{SL}$ ) was examined at the Muséum National d'Histoire Naturelle in Paris. One of the syntypes of Novacula tetrazona Bleeker (RMNH 6618, $92 \mathrm{~mm} \mathrm{SL}$ ) was examined at the Nationaal Natuurhistorische Museum in Leiden. The lot included two specimens, but the second one, $33 \mathrm{~mm} \mathrm{SL}$, is too small to be a type. The other syntype is believed to be in the Natural History Museum in London
(вмNH types now inaccessible due to moving of the fish collection). The illustration of $N$. tetrazona by Bleeker (1862: pl. 30, fig. 2) has the membrane of the first dorsal fin coming to a point at the spine tip instead of being expanded, lappet-like, as is typical of juvenile I. pavo. Martien van Oijen was asked to check the specimen, and he confirmed that the membrane is broad behind the spine and expanded at the tip. We therefore confidently place Novacula tetrazona in the synonymy of I. pavo.

Iniistius pavo is found over open stretches of sand, though often near coral reefs. Our specimens have been collected from 8 to 31 $\mathrm{m}$, but J.L.E. has observed this species to depths of $100 \mathrm{~m}$ (using mixed-gas rebreather diving gear).

Juveniles at Kahe Point, O'ahu, occur as solitary individuals on sand near hard substrate or some object in the sand. Unlike the other species of the genus in the Hawaiian Islands, they may forage briefly over hard bottom, though never far from their sand sanctuary. Adults usually range over large areas off Kahe Point. In other O'ahu locations with higher population density, they form aggregations with individual territories similar to the pattern observed in the other $\mathrm{Ha}$ waiian species except $I$. celebicus.

OTHER MATERIAL EXAMINED: Red Sea, Gulf of Aqaba, врвм 20811, $115 \mathrm{~mm}$; врвм 20851, 2: 233-287 mm; USNM 22295, $93 \mathrm{~mm}$. Gulf of Aden, Somalia $\left(12^{\circ} 0^{\prime} 6^{\prime \prime} \mathrm{N}, 50^{\circ} 56^{\prime}\right.$ 6" E), $202 \mathrm{~mm}$. Mauritius, врвм 20312, 195 $\mathrm{mm}$; USNM 348782, $37 \mathrm{~mm}$. Indonesia, Lombok, врвм 29872, $91 \mathrm{~mm}$. New South Wales, врвм $35029,40 \mathrm{~mm}$. Lord Howe Island, врвм 14930, $243 \mathrm{~mm}$. Marshall Islands, Kwajalein Atoll, врвм 37276, $74 \mathrm{~mm}$. Hawaiian Islands, O‘ahu, врвм 462-464, 3: 111$134 \mathrm{~mm}$; вРвм 528, 2: 148-214 mm; вРвм 641, $113 \mathrm{~mm}$; ВРВм 1758, $109 \mathrm{~mm}$; ВРВм $4712,305 \mathrm{~mm}$; вРвм 4715-4721, 10: 115$166 \mathrm{~mm}$; врвм 7309, $50 \mathrm{~mm}$; вРвм 7921, 4: 56-90 mm; вРвм 7968, $157 \mathrm{~mm}$; вРвм 31018, $22 \mathrm{~mm}$; вРвм 24792, 3: 44-118 mm; вРвм 32857, $16 \mathrm{~mm}$; ВРвм 37053, $188 \mathrm{~mm}$; вРвм 37128, $74 \mathrm{~mm}$; врвм 37276, $74 \mathrm{~mm}$. Maui, врвм 17647, $159 \mathrm{~mm}$. Hawai' i, врвм 287, 138 $\mathrm{mm}$. Society Islands, Tahiti, USNM 11476, 72 mm. Marquesas Islands, Nuku Hiva, врвм 
12601, 2: 25-45 mm. Pitcairn Islands, Pitcairn, врвм 16832, $266 \mathrm{~mm}$. Panama, Bahia Honda $\left(7^{\circ} 45^{\prime} \mathrm{N}, 81^{\circ} 32^{\prime} \mathrm{W}\right)$, USNM 321438 , $101 \mathrm{~mm}$.

\section{Iniistius umbrilatus (Jenkins) Plate III $D-H$}

Hemipteronotus umbrilatus Jenkins, 1901:53, fig. 10 (type locality, Hawaiian Islands); Jordan \& Evermann, 1905:333, fig. 141 (Hawaiian Islands).

DIAGNosis: Suborbital region with a broad band of small scales beginning with 67 rows just below eye and ending below corner of mouth (with 2-4 rows behind corner of mouth); gill rakers 16-19 (modally 17); body depth 2.5-3.2 in SL; origin of dorsal fin posterior to a vertical at rear edge of orbit, but anterior to upper end of preopercular margin; first two dorsal spines flexible, the first curved and shorter than longest dorsal soft ray; first dorsal spine of small juveniles variable in length but may be twice as long as longest dorsal soft ray; membrane between second and third dorsal spines incised threefourths or more length of third spine (in some juveniles connecting membrane nearly absent). Color of adults pale purplish gray, the edges of scales paler than centers, with a broad black bar (in which the scales may or may not be pale-edged) below about the last five dorsal spines and extending to level of lower edge of pectoral-fin base (on some individuals black bar is irregular with little dark pigment extending above lateral line); scales on abdomen below black bar bluish with a broad white posterior edge; a narrow whitish bar on head immediately posterior to vertical margin of preopercle; fins light gray without markings except for a small black area distally on first membrane of dorsal fin. Small juveniles nearly entirely dark brown to black with a vertical series of four white spots below base of first soft dorsal ray; with growth the dark brown is restricted to a narrow dark bar through eye, a broad bar across operculum linked midlaterally to one beneath pectoral fin, two close-set broad bars that extend across dorsal and anal fins, and a large semi- circular bar across caudal-fin base; remaining white areas with small dark brown blotches; with further growth the bars become narrower, the two into the dorsal fin develop an ocellated black spot there, and the dark blotches disappear. Largest specimen examined, врвм 16414, $202 \mathrm{~mm}$, obtained from a Honolulu fish market.

REMARKs: This species is known only from the Hawaiian Islands; our specimens have been collected over sand at depths of 6$40 \mathrm{~m}$.

Iniistius umbrilatus is the most abundant species in the transect area at Kahe Point, O'ahu, by a factor of 5 over I. celebicus, the next most common species. It settles out at about $12 \mathrm{~mm}$ SL to sandy areas, usually close to a reef. The juveniles frequently form small groups with individuals spaced $0.3-1 \mathrm{~m}$ apart. Newly settled juveniles have been seen in every month of the year, but a distinct recruitment peak was noted in March and April. The transect population is at a maximum in August when most individuals are juveniles. It dwindles to a minimum in January when most are adults. The diminution in the population of juveniles is certainly partly due to predation, particularly by synodontids. Tracbinocephalus myops, generally found buried in the sand, was observed capturing juveniles. But it is also expected from the effects of large winter surf and a general movement away from the close proximity to the reef with maturity. On average, the population is diminished by a factor of 9 between high and low population months in any given year. Recruitment has varied by a factor of 5 between high and low recruitment years.

Adult females maintain separate territories within the larger territory of a dominant male who patrols the area and periodically visits each female. One spawning episode was observed in February during the late afternoon $30 \mathrm{~min}$ before sunset with a falling tide and a full moon that evening. The large male, with a sharply demarcated dark anterior half of the body, approached the females in his harem from behind. Some females swam away, with the male following for about $10 \mathrm{~m}$ before breaking off and approaching another female. When the male approached a receptive fe- 
male, both rose side by side in an unhurried manner to a height of $0.5-1 \mathrm{~m}$ above the bottom. Actual spawning was accompanied by a wiggling motion, followed by separation and return to the bottom. During this reproductive period, interaction was observed between males at territory boundaries. Most often this was an approach by males to within $1 \mathrm{~m}$, then turning broadside to each other before swimming away. Rarely, two males were observed after the initial broadside maneuver to engage in a brief, fast-moving, rolling contact before disengaging.

MATERIAL EXAMINED: Hawaiian Islands, Necker Island, вРвм 10793, $202 \mathrm{~mm}$. O'ahu, вРвм $600,140 \mathrm{~mm}$; вРвм 4704-4707, 7: 105$198 \mathrm{~mm}$; вРвм 8516, $98 \mathrm{~mm}$; вРвм 12533, $146 \mathrm{~mm}$; вРвм 15411, $141 \mathrm{~mm}$; вРвм 16414, 2: 200-202 mm; вРвм 22738, $137 \mathrm{~mm}$; вРвм 28148, $102 \mathrm{~mm}$; врвм 32858, 3: 17-32 mm; врвм $36870,34 \mathrm{~mm}$; вРвм $37127,2: 30-57$ $\mathrm{mm}$; врвм 37190, $47 \mathrm{~mm}$; врвм 37205, 2: 21 $174 \mathrm{~mm}$. Maui, врвм 36785, $32 \mathrm{~mm}$. Hawai' ${ }^{\prime}$, вРвм 78980, 3: 81-134 mm.

\section{ACKNOWLEDGMENTS}

We thank those who have assisted us in collecting specimens of Hawaiian razorfishes, notably Charles J. Boyle, Bruce A. Carlson, Jane B. Culp, Ofer Gon, Therese Hayes, Richard M. May, Mark S. Mohlmann, Lewis H. Strauss, and A. Bradley Tarr. We are grateful also to Loreen R. O'Hara for X rays and to Arnold Y. Suzumoto for curatorial assistance.

\section{Literature Cited}

Allen, G. R., and D. R. Robertson. 1994. Fishes of the tropical eastern Pacific. Crawford House Press, Bathurst, N.S.W.

Allen, G. R., D. F. Hoese, J. R. Paxton, J. E. Randall, B. C. Russell, W. A. Starck II, F. H. Talbot, and G. P. Whitley. 1976. Annotated checklist of the fishes of Lord Howe Island. Rec. Aust. Mus. 30:365-454.

Bleeker, P. 1856. Beschrijvingen van nieuwe en weinig bekende vischsoorten van Manado en Makassar, grootendeels verzameld op eene reis naar den Molukschen Archipel in het gevolg van den GouverneurGeneraal Duymaer van Twist. Acta Soc. Sci. Indo-Neêrl. 1:1-80.

1859. Derde bijdrage tot de kennis der ichthyologische fauna van Bali. Nat. Tijdschr. Neder. Indie 17:141-175.

. 1862. Atlas ichthyologique des Indes Orientales Néêrlandaises, publie sous les auspices du Gouvernement colonial néêrlandais. Tome I. Scaroïdes et Labroïdes. Frédéric Muller, Amsterdam.

Cuvier, G. 1814. Observations et recherches critiques sur différentes poissons de la Méditerranée et à leur occasion, sur des poissons des autres mers, plus ou moins liés avec eux. Bull. Soc. Philomath. Paris 1814:80-92.

Cuvier, G., and A. Valenciennes. 1840. Histoire naturelle des poissons, vol. 14. PitoisLevrault, Paris.

Dor, M., and A. Fraser-Brunner. 1977. Record of Hemipteronotus melanopus (Teleostei: Labridae) from the Red Sea. Isr. J. Zool. 26:135-136.

Eschmeyer, W. N., ed. 1998. Catalog of fishes. 3 vols. California Academy of Sciences, San Francisco.

Fowler, H. W. 1904. A collection of fishes from Sumatra. J. Acad. Nat. Sci. Phila., ser. 2, 12 (4): 495-560. . 1928. The fishes of Oceania. Mem. B. P. Bishop Mus. 10: iii +540 .

1944. Results of the fifth George Vanderbilt expedition (1941) (Bahamas, Caribbean Sea, Panama, Galápagos Archipelago and Mexican Pacific islands). The fishes. Monogr. Acad. Nat. Sci. Phila. 6:57-529.

. 1956. A synopsis of the fishes of China. Part VII. The perch like fishes (complete). Q. J. Taiwan Mus. (Taipei) 9 (3 \& 4): 161-354.

Francis, M. P. 1993. Checklist of the coastal fishes of Lord Howe, Norfolk, and Kermadec Islands, Southwest Pacific Ocean. Pac. Sci. 47:136-170.

Gill, T. N. 1862. Catalogue of the fishes of Lower California in the Smithsonian Institution, collected by Mr. J. Xantus. Proc. Acad. Nat. Sci. Phila. 14 (3): 140-151. 
Gosline, W. A., and V. E. Brock. 1960. Handbook of Hawaiian fishes. University of Hawai'i Press, Honolulu.

Grove, J. S., and R. J. Lavenberg. 1997. The fishes of the Galápagos Islands. Stanford University Press, Stanford, California.

Günther, A. 1862. Catalogue of the fishes in the British Museum. Catalogue of the Acanthopterygii Pharyngognathi and Anacanthini in the collection of the British Museum. British Museum, London.

Herre, A. W. 1953. Check list of Philippine fishes. U.S. Fish Wildl. Serv. Res. Rep. 20:1-977.

Hoover, J. P. 1993. Hawaii's fishes. Mutual Publishing, Honolulu.

Jenkins, O. P. 1901. Descriptions of new species of fishes from the Hawaiian Islands belonging to the families Labridae and Scaridae. Bull. U.S. Fish Comm. 19 (1899): 45-65.

- 1903. Report on collections of fishes made in the Hawaiian Islands, with descriptions of new species. Bull. U.S. Fish Comm. 22 (1902): 417-511.

Jordan, D. S. 1891. A review of the labrid fishes of America and Europe. Rep. U.S. Fish Comm. 15:599-699.

Jordan, D. S., and B. W. Evermann. 1903. Descriptions of new genera and species of fishes from the Hawaiian Islands. Bull. U.S. Fish Comm. 22 (1902): 161-208. . 1905. The shore fishes of the Hawaiian Islands, with a general account of the fish fauna. Bull. U.S. Fish Comm. 23, pt. 1 (1903): xxviii + 574.

Jordan, D. S., and R. E. Richardson. 1909. A catalog of the fishes of the island of Formosa, or Taiwan, based on the collections of Dr. Hans Sauter. Mem. Carnegie Mus. 4 (4): 159-204.

Laboute, P., and R. Grandperrin. 2000. Poissons de Nouvelle-Calédonie. Editions Catherine Ledru, Nouméa.

Masuda, H., C. Araga, and T. Yoshino. 1975. Coastal fishes of southern Japan. Tokai University Press, Tokyo.

Masuda, H., K. Amaoka, C. Araga, T. Uyeno, and T. Yoshino, eds. 1984. The fishes of the Japanese Archipelago. Tokai University Press, Tokyo.
Myers, R. F. 1999. Micronesian reef fishes. Coral Graphics, Guam.

Myers, R. F., and T. J. Donaldson. 1996. New and recent records of fishes from the Mariana Islands. Micronesica 28 (2): 207266.

Nguyen, Tri-thuc. 1974. Osteological studies on the labrid fishes (Family Labridae) of Japan-Morphology, taxonomy and phylogeny. Ph.D. thesis, Ocean Research Institute, University of Tokyo.

Parenti, P., and J. E. Randall. 2000. An annotated checklist of the species of the labroid fish families Labridae and Scaridae. Ichthyol. Bull. J. L. B. Smith Inst. Ichthyol. 68:1-97.

Peters, W. C. H. 1877. Übersicht der während der von 1874 bis 1876 unter dem Commando der Hrn. Capitän z. S. Freiherrn von Schleinitz ausgeführten Reise S. M. S. "Gazelle" gesammelten und von der Kaiserlichen Admiralität der Königlichen Academie der Wissenschaften übersandten Fische. Montasber. Akad. Wiss. Berlin (1876): 831-854.

Playfair, R. L., and A. Günther. 1867. The fishes of Zanzibar. John van Voorst, London.

Randall, J. E. 1965. A review of the razorfish genus Hemipteronotus (Labridae) of the Atlantic Ocean. Copeia 1965 (4): 487-501.

. 1996. Shore fishes of Hawai'i. University of Hawai'i Press, Honolulu. . 1999. Report on fish collections from the Pitcairn Islands. Atoll Res. Bull. 461:136.

Randall, J. E., and R. C. Anderson. 1993. Annotated checklist of the epipelagic and shore fishes of the Maldive Islands. Ichthyol. Bull. J. L. B. Smith Inst. Ichthyol. 59:1-47.

Randall, J. E., and M. L. Bauchot. 1993. Case 2842. Naucrates Rafinesque, 1810 and Xyrichtys Cuvier, 1814 (Osteichthyes, Perciformes): Proposed conservation. Bull. Zool. Nomencl. 50 (4): 277-281.

Randall, J. E., P. S. Lobel, and E. H. Chave. 1985. Annotated checklist of the fishes of Johnston Island. Pac. Sci. 39:24-80.

Randall, J. E., G. R. Allen, and R. C. Steene. 1990. Fishes of the Great Barrier Reef and 
Coral Sea. University of Hawai'i Press, Honolulu.

Randall, J. E., H. Ida, K. Kato, R. L. Pyle, and J. L. Earle. 1997. Annotated checklist of the fishes of the Ogasawara Islands. Monogr. Natl. Sci. Mus., Tokyo 11:174.

Regan, C. T. 1905. Description de six poissons nouveaux faissant partie de la collection du Musée d'Histoire Naturelle de Genève. Rev. Suisse Zool. 13:389-393.

Richardson, J. 1846. Report on the ichthyology of the seas of China and Japan. Rep. Br. Assoc. Adv. Sci. (1845): 187-320.

Schultz, L. P., and Collaborators. 1960. Fishes of the Marshall and Marianas Islands. Bull. U.S. Natl. Mus. 202, vol. 2: $\mathrm{ix}+438 \mathrm{pp}$.

Shao, K.-T. 1986. Thirteen new records of the labrid fishes (Pisces: Labridae) from Taiwan. J. Taiwan Mus. 39 (1): 181-196.

Shen, S.-C., and H.-S. Yeh. 1987. Study on the razorfishes genus Xyrichtys (Labridae) of Taiwan. J. Taiwan Mus. 40 (2): 61-71.

Smith, M. M., and P. C. Heemstra, eds. 1986.
Smith's sea fishes. Macmillan South Africa, Johannesburg.

Snyder, J. O. 1904. A catalogue of the shore fishes collected by the steamer Albatross about the Hawaiian Islands in 1902. Bull. U.S. Fish Comm. 22 (1902): 513-538.

Steindachner, F. 1900. Fische aus dem Stillen Ocean. Ergebnisse einer Reise nach dem Pacific (Schauinsland, 1896-1897). Anz. Akad. Wiss. Wien 16:174-178.

Victor, B. C., G. M. Wellington, and C. Caldow. 2001. A review of the razorfishes (Perciformes: Labridae) of the eastern $\mathrm{Pa}-$ cific Ocean. Rev. Biol. Trop. 49:101-110.

Waite, E. R. 1901. Notes on fishes from Western Australia, No. 1. Rec. Aust. Mus. 4:41.

Wass, R. C. 1984. An annotated checklist of the fishes of Samoa. NOAA Tech. Rep. NMFS SSRF-781: 1-43.

Winterbottom, R., and R. C. Anderson. 1997. A revised checklist of the epipelagic and shore fishes of the Chagos Archipelago, central Indian Ocean. Ichthyol. Bull. J. L. B. Smith Inst. Ichthyol. 66:1-28. 